\title{
Customer Relationship Management and Intercollegiate Athletics: Opportunities and Benefits for Smaller Institutions
}

\author{
Charles F. Harrington ${ }^{1, *}$ \\ ${ }^{1}$ George Dean Johnson, Jr. College of Business and Economics, South Carolina, USA \\ *Corresponding author: George Dean Johnson, Jr., College of Business and Economics, University of South Carolina \\ Upstate, 800 University Way, Spartanburg, South Carolina 29303, USA. E-mail: charrington@uscupstate.edu
}

Received: October 29, 2013

Accepted: December 2, 2013

Online Published: December 9, 2013

doi:10.5430/mos.v1n1p1

URL: http://dx.doi.org/10.5430/mos.v1n1p1

\begin{abstract}
Customer relationship management (CRM) strategies have been proven of significant benefit to sports teams and organizations in their attempts to attract and retain fan loyalty as well as to maximize profits. Single game and season ticket sales, merchandizing, sport and program information and communication, and athletic giving can each be increased through the adoption and utilization of CRM. Although primarily leveraged by professional sports teams and some larger (NCAA Division I) university programs, CRM strategies can also be of direct and considerable benefit to smaller institutions.
\end{abstract}

Keywords: customer relationship management; college athletics; athletic conferences; marketing

\section{Introduction}

Establishing and building upon customer loyalty, cost reduction, and profit maximization are fundamental tenants of the business enhancement strategy Customer Relationship Management or CRM. A solid CRM strategy collects, analyzes, and reports information gathered from multiple data sources within (and often outside of) an organization, that provides accurate, timely, and real-time information on customers (Reinartz, et al, 2004). Such aggregate data and information, properly leveraged, can maximize engagement with customers in important contact areas for athletic programs, including sales, customer support, and marketing in order to make effective and efficient informed decisions regarding up-selling and cross-selling opportunities in order to more efficiently execute target marketing strategies and competitive market positioning.

Once thought only as a business marketing application, CRM has evolved into a customer-centric philosophy permeates an entire organization. Three fundamental elements comprise a fruitful CRM enterprise: individuals, processes, and technology. The people throughout the entire company-from the President to every employee should endeavor to understand and support CRM. Businesses processes must support its CRM initiative, often from the position of, "How might this particular process more effectively and efficiently serve our existing and future customers?” Organizations must identify and implement the right technology necessary to facilitate and sustain these value-added processes, provide timely, valid, and reliable data to employees, and be easy enough to understand and use. If one of these three basics is not complete, the CRM structure potential and most likey benefits will likely be conceded.

An extremely useful strategy to understand more thoroughly customer needs and behaviors, customer relationship management allows organizations to develop even stronger relationships with the customer base Verhoef, 2003). Effective and sustained customer relationships are mission critical to business growth and organizational success. CRM brings together myriad pieces of information about customers, sales, marketing saturation and impact, responsiveness, and market trends.

CRM is used advantageously to assist businesses in leveraging people, processes, and technology to obtain understanding into the behavior and value of their customers. This understanding can facilitate improved customer service, increased call center/telemarketing efficiency, increased cross- and up-sell opportunities, simplified sales and marketing processes, enhanced customer profiling and targeting, reduced costs, and increased market share and 
overall profitability (Chen, I.J, 2003).

\section{CRM and Athletics}

Revenue generated from the sports industry totaled nearly $\$ 220$ billion dollars, nearly rivaling that of banking and transportation (Brown, 2003). According to Street \& Smith's Sports Business Journal, revenue generated from sports came from advertising, equipment, retail, and travel. Discovering and exploiting methods to leverage the loyalty of sports fans can assist both professional and collegiate sports teams and conference increase market share, and by default, maximize profits.

A national, divisional, or conference championship, terrific season, or an outstanding athlete are often enough to increase game or season ticket sales or draw a sold out stadium or arena, but many teams and athletic departments are faced with the reality that they require something more than "buzz" to help fill seats when a team's win-loss record is something less than stellar. When losses exceed wins, or the team has a mediocre season, foam fingers, coupons, or other promotional gimmicks simply are insufficient strategies to gain and retain fan loyalty. Customer relationship management, properly utilized, can identify and engage occasional customers and ardent fans in ways that create loyalty, increase cross- and up-selling, and encourage philanthropic giving, regardless of how often the team wins.

Among the principle objectives of any sports team or conference is the generation and maximization of revenue. Athletic programs can accomplish development through myriad revenue streams. Among these are multi-media rights, donations, single game and season ticket sales, television contracts, clothing, and concessions. The athletics conference or league most frequently controls television revenue, if such revenue is realized. Most Division I athletic programs outsource multi-media rights, concessions, and apparel sales to a third party. Ticket sales remain the reliable and primary revenue source over which an athletic department or team has significant control. Such departments are determined to increase season and single game ticket sales. Ticket sales also account for the largest proportion of both professional teams and university athletic department budgets. In most cases, these programs handle data and information regarding thousands of season ticket and individual games ticket sales customers. Many have elected to collect, analyze, and report these important data by using database marketing techniques. Recently, customer relationship management techniques and strategies have developed in order to support in this process.

\section{CRM and Professional Athletics}

For many professional teams, a crucial tactic to gaining and retaining fan loyalty is facilitated through customer relationship management. Teams and athletic programs have leveraged CRM to the benefit of not only fans, but for their bottom line -increased attendance, market share, and revenue.

As early as 1995, the San Diego Padres implemented a CRM program and were the first major league baseball franchise to initiate a fan-loyalty rewards program. Since then, attendance has risen to 2 million attendees per year. The team also has witnessed the average number of games attended by fans increase to nearly 11 million per season, up from 6.5 in 1995.

Through its fan/customer reward program, the team offers fans a "team card" to use at one of many stadium kiosks. $\mathrm{Bu}$ recording their attendance with the kiosk, fans can earn discounts on future game tickets, food, beverages, and apparel and merchandise from the Padres store. Discounts are based upon the accumulated points from game attendance and specific purchases. In return, the Padres obtain detailed information about their fans, and track spending habits at the game. This database currently contains more than 250,000 records. These data have been leveraged to offer special discounts to certain demographic groups, increased single and season ticket sales, increased merchandising revenue, and also have dramatically increased their return rates from email "direct mail" marketing campaigns.

Although programs such as CRM help increase revenue for many professional organizations, a number of those initiatives' started initially as a basic service to the team's fan base. Recently, the Pheonix Suns basketball team began to permit their single game and season ticket holders to resell tickets through the team's Web portal, again another value added benefit to fans.

Another very novel use of customer relationship management software is to track the numerous items that are inadvertently left behind accidentally by fans. Some are using CRM to track and return "lost and found" items. Tracking such variables as description and picture of item left behind, date found, and the location of the item found in the stadium or arena. The items are then cataloged, tagged, and safety stored in a secure location until they can be 
returned to their rightful owners. One team that has successfully used this strategy is the Chicago White Sox. Since deploying their CRM in this matter, the Sox organization estimates that it has been able to return more than 50 percent of lost items.

Professional hockey teams, such as the Carolina Hurricanes are also leveraging CRM creatively. The team employs wireless Internet throughout their arena in an attempt to boost fan interest and support. Fans have access to the team's "fans only" website, a video stream of the game, enhanced game commentary and "behind the scenes" supplements. Fans can also use the team's internet access to place orders for in-seat food and beverages, and purchase apparel and other team merchandise.

Many teams are amenable to openly discuss their CRM processes, goals, and strategies, especially organizations in other sports markets. In reality, television, movies, restaurants, and other avenues of entertainment openly compete for attendance to sporting events. By intelligently leveraging CRM, sports teams and organizations can more effectively market, by custom tailored messaging, their various events. Regrettably, many professional sports teams have been slow to appreciate the competitive marketing advantages that CRM can provide.

\section{Benefits of CRM to College Athletics}

CRM helps colleges and universities build databases about their customers that describe relationships in sufficient detail so that sales personnel can access that information to potentially match fan and customer needs with products offered, remind customers of specific ticket offers, and help the sport organization track what their customers have purchased. For most sport organizations, it starts with some simple questions: how do we increase fan attendance and revenue with the given budget that we have? Are we selling and servicing as efficiently as possible? How are we tracking sales leads? How can we convert single game ticket purchases into season ticket holders? How can get those individuals holding season tickets or purchasing single game tickets in one particular sport to purchase tickets for other sports? How can we increase fan/customer purchases of athletics and/or university/college apparel? And finally, how can we increase the number of single game and season ticket holders that contribute financially to the University's athletic department?

There are a number of important goals that would appear most appropriate for CRM utilization in college athletics. These include: identification of profitable/repeat customers; understanding online/offline customer behavior; increasing sales and affinity though real-time, one-to-one marketing campaigns; helping retain the "right" customers; helping increase fan loyalty and affinity; maximizing overall revenue generated per customer through all channels; and targeting and increasing value for sponsors through data mining (Butler, 2012).

Without question, the first step to increasing the fan base and elevating fan/customer loyalty is to understand more fully the needs and purchasing behavior of customers. This knowledge base will drive the strategies by which institutions move to address the increased ticket sales, loyalty, and economic activity.

\section{CRM Utilization by NCAA Division I Institutions}

Arizona State University (ASU) was the first major athletic department to embrace and successfully implement this strategy. ASU's CRM program, called the Devil's Domain (after the school's Sun Devil mascot), includes a Web site, a rewards program, screensavers with customized messages, discounts at the team store and on future ticket purchases, and coupons for free or discounted food and beverages.

A number of other large (NCAA Division I) colleges and universities constitute examples of how they are leveraging the technology to their advantage in value and profit maximization. Two are particularly noteworthy. In early 2011, the University of Denver partnered with a major CRM firm to implement ticketing, marketing, and fund raising solutions in their athletics department. DU will be able to more efficiently cultivate new donor relationships, while providing important opportunities for online fundraising as well. DU plans to leverage the CRM system to help fuel athletic donation revenues as well. The University of Minnesota also has adopted a fully-integrated CRM focused on ticketing, game day information, fan/customer appreciation, and fundraising. The school's newly developed online portal will benefit fans directly with the following added features: complement the existing University athletics brand; integrated game day information; full access to manage their account online; full history of past purchases and donations; recommended purchases based on consumer behavior; and a full calendar listing of Golden Gophers games and events.

Given the sheer size of current and potential fan/customers for athletics programming at the larger colleges and 
universities, the scope and complexity of their administrative operations, and the potential economic benefits derived from increased attendance, merchandizing, and personal and corporate fundraising, affords the opportunity and benefit of employing full-scale CMS applications. However, the cost associated with software procurement, modification, and implementation is non-trivial, often extending into the several hundred thousand dollar range.

\section{Potential Leverage by Smaller Institutions, Conferences, and Divisions}

Many smaller institutions, conferences, and divisions simply do not have the critical mass in existing or potential fan base, nor do they have the resources (people, time, and money) to adopt, plan, and implement a comprehensive customer relationship management system. For many smaller institutions, individual and season ticket sales, apparel sales, individual giving to athletics (outright gifts, scholarships, operating support) are minimal.

Without question, an increase in the athletics fan/customer base as well as increase in existing fan loyalty can have significant benefit for the athletics department, the institution, and the communities in which the institutions are located. Many smaller institutions, both public and private, experience significant difficulty in balancing their athletics budget, particularly in tough economic times. Even modest increases in ticket sales can have a direct and positive impact on the athletic programs bottom line.

Increased season and individual game ticket sales can also have profound benefits on fan loyalty. When college athletic events become the marquee community "must attend" social events, the increased attendance leads to increased loyalty. Increased fan loyalty can and does result in increased giving to athletics departments and athletic scholarships. With even the most modest benefits derived from an appropriately leveraged Customer Relationship Management system, the local college team can become "our team".

There is a substantial research literature which clearly establishes the direct economic impact that college athletics has on its surrounding community(ies) (Lentz \& Laband, 2008). Particularly during home athletic contests, there is a direct economic benefit derived by hotel and restaurant sectors from visiting athletic teams, season and single game ticket holders, and students. The service industry, including gas stations, convenience stores, and local retail have also been shown to benefit. This issue is particular important for athletics programs located at smaller institutions as well as those schools located in smaller rural areas, where the institution is often the single largest economic driver in the immediate area.

There are elements of CMS that can prove inordinately useful to smaller athletic departments and their teams, including but not limited to; increased fan/customer loyalty through email and SMS marketing; increased student moral (including prospective students); athletic and institutional branding and image enhancement; cross-selling to increase recognition and attendance at other college or university sporting events; up-selling to increase fan/customer engagement from individual/season ticket holder to athletics donor; and the integration of an athletics CMS with existing college/university donor database.

\section{Leveraging the Power of Customer Relationship Management}

Clearly, one of the biggest benefits to CRM is the ability for the organization to capture and strategically leverage data about current and potential customers. Having access to data allows organizations to improve their customer response by offering personalized and customized marketing campaigns (Neslin \& Shankar, 2009). Personalization focuses on building a meaningful one-to-one relationship with each customer by understanding their needs and helping them satisfy those needs efficiently and effectively. Customization makes customers stakeholders in the buying process by giving them a proactive role in the product selection process CRM allows sport organizations to "design, deployment, and evaluation of channels to enhance customer value through effective customer acquisition, retention, and development” (Nelsin, Grewal, Leghorn et al., 2006, p. 70). This has allowed the organization to own the information that it spends money to generate.

The process in deciding whether or not to invest in a CRM initiative is significant; therefore it is essential that the organization as a whole has bought in to the idea of database marketing. Unlike some departments that operate autonomously, a CRM strategy relies on numerous departments being able to communicate to be effective.

This commitment is more difficult at the collegiate level than in professional sport organizations. A professional sports organization, which by definition is a for profit firm, can hire a long-term employee exclusively to oversee the CRM initiative. This is more challenging within a university setting, where typically employees are more transient in nature. The employee hired needs to able to bridge the gap between the technical aspects of the software and the sales related 
function of the system. In addition, the employee needs to have a key understanding of the main function of the system, which is to increase sales and service.

Ultimately, the organization needs to embrace an analytical approach towards attracting potential customers. The advancement of interactive technology, information processing, and CRM systems has made personalized marketing campaigns a tangible model for sport organizations to gain a competitive advantage in the marketplace. One-to-one marketing employs an extreme form of segmentation that creates a virtual dialogue where the customer touch points are two-way: I act and I expect the retailer to (re)act in a certain way (Adamson, 2008).

Implementing a CRM system is a long, potentially expensive, and challenging process. The organization needs to allot time to decide on a system, implement that system, and realize the rewards of this approach. Organizations need to take their time and make sure that they have a good understanding about the front end cost of CRM.

The marketing challenges that sport organizations face are still present. What has changed is the way these organizations choose to market their programs. Implementing a CRM strategy has allowed organizations to target specific fans within the marketplace that would be receptive to attending a specific sporting event. This allows them to better determine where to allocate their marketing dollars. However, a caveat is warranted; once a database is built, organizations can be tempted to overuse the system for short term sales gains by pushing too many offers and communication to fans (Knowledge, 2005).

CRM will also help sport organizations define their consumers' buying patterns. Understanding these buying patterns will be more important as organizations learn how to track the spending patterns of consumer auxiliary revenue such as concessions, parking, and merchandise. Thus, sport organizations can utilize CRM as the core database and move customers up the value chain.

\section{Conclusion}

Customer relationship management is an integral component of any administrative strategy in developing athletics program support and increasing revenues. From increasing ticket sales, merchandizing, and fan loyalty, to increased financial giving to athletics programs and student athletic scholarships, CRM can be of direct benefit to all sports programs, regardless of size, in obtaining their goals and objectives. The three most important considerations in adopting a CMS are the impact on people, the processes involved in collecting, analyzing, and report information, and technology. Even the smallest athletic program or conference can benefit from knowing more about their customer base and leveraging that information to sell more tickets, convert single ticket buyers to season ticket holders, increase revenue from apparel and concessions, and identify and cultivate individuals who might be likely to contribute financially to the athletic program or conference.

\section{References}

Adamson, A. P. (2008). Brand Digital: Simple Ways Top Brands Succeed in the Digital World. New York; NY: Palgrave Macmillan.

Ball, E. (2010). Who Is No. 1? Ranking the 30 MLB Teams' Fan Bases. Bleacher Report. Retrieved October 20, 2010 from http://bleacherreport.com

Brown, M.T. (2003). An Analysis of Online Marketing in the Sport Industry: User Activity, Communication Objectives, and Perceived Benefits. Sport Marketing Quarterly, 12(1), 48-55.

Butler, D. (2012). How colleges are adopting pro concepts in ticketing. Sports Business Journal, June 4-10, 2012.

Chen, I.J., \& Popvich (2003). Understanding customer relationship management (CRM): People, process and $\begin{array}{lllll}\text { technology. } \quad \text { Business } & \text { Process }\end{array}$ http://dx.doi.org/10.1108/14637150310496758

Knowledge (2005). Teams cozy up to the fans with CRM"s, personalized marketing"strategy, Knowledge@W.P Carey. Retrieved from http://knowledge.wpcarey.asu.edu/article.cfm?articleid=1163

Lentz, B., \& Laband, D. (2008). The impact of college athletics on employment in restaurant and accommodations industries. Working Paper. The North American Association of Sports Economists. June 2008.

Nelsin, S., Grewal, D., Leghorn, R., Shankar, V., Teering, M.L., Thomas, J.S., \& Verhoef P.C. (2006). Challenges and opportunities in multichannel management. Journal of Research Science, 9(2), 95-113. 
Neslin, S., \& Shankar, V. (2009). Key issues in multichannel customer management: Current knowledge and future directions. Journal of Interactive Marketing, 23(1), 70-81. http://dx.doi.org/10.1016/j.intmar.2008.10.005

Payne, A., \& Frow, P. (2005). A strategic framework for customer relationship management. Journal of Marketing, 69, 167-176. http://dx.doi.org/10.1509/jmkg.2005.69.4.167

Reinartz, W., Krafft, @. \& Hoyer, D. (2004). The customer relationship management process: its measurement and impact on performance. Journal for Marketing Research, 41(3), 293-305. http://dx.doi.org/10.1509/jmkr.41.3.293.35991

Verhoef, Peter. (2003). Understanding the effect of customer relationship management efforts on customer retention and customer share development. The Journal of Marketing, 67(4), 30-45. http://dx.doi.org/10.1509/jmkg.67.4.30.18685 